\title{
FIKIH SOSIAL \\ (Pendekatan Teori Hubungan Otoritas dan Konflik Sosial Ralf Dahrendolf dan Kajian Kasus Konflik Otoritas Sunni-Syi'ah di Sampang Madura)
}

\author{
Oleh: \\ Miftahul Ulum ${ }^{1}$ \\ Email: miftahul_ulum2001@yahoo.com
}

\begin{abstract}
Ralf Dahrendorf's conflict theory states that the structural changes can be classified on the basis of their extremities and based on their abrupt or unexpected levels. In this case Ralf Dahrendorf admits that his theory of emphasis on conflict and social change is a one-sided perspective of social reality. This is because although the theory of structural functionalism and conflict theory is perceived by Ralf Dahrendorf as a valid perspective in approaching social reality, it includes only a part of the social reality that should be. Both theories are incomplete when used separately, and therefore should be used together, in order to obtain a complete picture of social reality. As an example of case studies, the intra-religious authoritative conflict occurring in Sampang between the Sunni and Shite schools is a flow rush that has reduced social harmonization among the Sampang and Madurese communities in general, causing intense social tensions. Sociologically, the existence of ulema among the Madurese is not only regarded as a religious elite, but also as a non-formal leader by the Madurese people who are considered to have social authority to determine life and community life.
\end{abstract}

Keywords: social conflict, Ralf Dahrendolf, Sunni-Shiite Conflicts

\section{Pendahuluan}

Sosiologi adalah ilmu yang mempelajari tentang fenomena sosial yang terjadi dalam masyarakat ${ }^{2}$. Fenomena sosial dalam masyarakat banyak

${ }^{1}$ Dosen STAI Syaichona Moh. Cholil Bangkalan, Peserta Program Doktor Hukum Islam Pascasarjana UIN Sunan Ampel Surabaya.

${ }^{2}$ Narwoko, J Dwi. dan Bagong Suyanto. Sosiologi Teks Pengantar dan Terapan, ( Jakarta: Kencana Predana Media Group, 2006), hlm. 16 
ragamnya kadangkala fenomena sosial berkembang menjadi suatu masalah sosial akibat perbedaan cara pandang mengenai fenomena tersebut ${ }^{3}$.

Dalam menyelesaikan masalah sosial dibutuhkan suatu teori untuk menyelesaikannya. Teori- teori tersebut lahir dari pengalaman-pengalaman yang terjadi dalam kehidupan sehari-hari. Karena setiap individu mengalami pengalaman yang berbeda maka teori yang muncul juga akan berbeda antara satu individu dengan individu lainnya. Disimpulkan bahwa tidak ada teori yang dapat menyeluruh membahas mengenai masalah sosial di masyarakat ${ }^{4}$.

Di zaman modern ini, orang dengan berbagai aktivitas dan kepentingan silih berganti ${ }^{5}$, kadang dapat membuat seorang individu atau suatu kelompok mengalami disjungsi atau persinggungan dengan individu atau kelompok yang lain yang akan mengakibatkan konflik6.

Konflik yang berkepanjangan kadang dapat memperburuk tatanan sosial masyarakat. Namun, konflik juga berperan positif dalam memperkuat persatuan dan menghilangkan konflik intern dalam suatu kelompok. Konflik apa pun bentuknya merupakan sesuatu yang wajar terjadi. Konflik senantiasa ada dalam setiap sistem sosial. Dapat dikatakan konflik merupakan suatu ciri dari sistem sosial.

\section{Pengertian Konflik}

Konflik berasal dari kata kerja Latin configere yang berarti saling memukul. Secara sosiologis, konflik diartikan sebagai suatu proses sosial antara dua orang atau lebih (bisa juga kelompok) dimana salah satu pihak

\section{${ }^{3}$ Ibid}

${ }^{4}$ Kahairuddin, Sosiologi Hukum, (Jakarta: Sinar Grafika, 1991), hlm. 36

5 Philastrid, S. Susanto, Pengantar Sosiologi dan Perubahan Sosial, (Jakarta: Binacipta, 1983), hlm. 42

${ }^{6}$ Konflik pada dasarnya adalah sesuatu yang tidak terhindarkan dalam kehidupan kita. Konflik merupakan bagian dari interaksi sosial yang bersifat disosiatif. Konflik ini jika dibiarkan berlarut-larut dan berkepanjangan serta tidak segera ditangani akan menimbulkan terjadinya disintegrasi sosial suatu bangsa. Suatu keadaan yang memiliki peluang besar untuk timbulnya konflik adalah perbedaan. Perbedaan yang dimaksud adalah perbedaan kepentingan. Dahrendorf, Ralf, Class and Class Conflict in Industrial Society, (Stanford CA: Stanford University. 1959), hlm. 5 
berusaha menyingkirkan pihak lain dengan menghancurkannya atau membuatnya tidak berdaya ${ }^{7}$.

Teori konflik yang muncul pada abad ke sembilan belas dan dua puluh dapat dimengerti sebagai respon dari lahirnya dual revolution, yaitu demokratisasi dan industrialisasi, sehingga kemunculan sosiologi konflik modern, di Amerika khususnya, merupakan pengikutan, atau akibat dari, realitas konflik dalam masyarakat Amerika. Selain itu teori sosiologi konflik adalah alternatif dari ketidakpuasaan terhadap analisis fungsionalisme struktural Talcot Parsons dan Robert K. Merton, yang menilai masyarakat dengan paham konsensus dan integralistiknya. Teoritisi konflik melihat masyarakat sebagai berada dalam konflik yang terus menerus diantara kelompok dan kelas, sekalipun Marx memusatkan perhatiannya pada pertentangan antar kelas. Untuk pemilikan atas kenyataan yang produktif, para teoritisi konflik modern berpandangan sedikit lebih sempit. Mereka melihat perjuangan meraih kekuasaan penghasilan sebagai suatu proses yang berkesinambungan terkecuali satu hal dimana orang-orang muncul sebagai penantang kelas, bangsa, kewarganegaraan dan bahkan jenis kelamin.

${ }^{7}$ Konflik dilatarbelakangi oleh perbedaan ciri-ciri yang dibawa individu dalam suatu interaksi. perbedaan-perbedaan tersebut diantaranya adalah menyangkut ciri fisik, kepandaian, pengetahuan, adat istiadat, keyakinan, dan lain sebagainya. Dengan dibawa sertanya ciri-ciri individual dalam interaksi sosial, konflik merupakan situasi yang wajar dalam setiap masyarakat dan tidak satu masyarakat pun yang tidak pernah mengalami konflik antar anggotanya atau dengan kelompok masyarakat lainnya, konflik hanya akan hilang bersamaan dengan hilangnya masyarakat itu sendiri. Dalam sosiologi, kita mengenal adanya teori konflik yang berupaya memahami konflik dari sudut pandang ilmu sosial. Teori konflik adalah sebuah teori yang memandang bahwa perubahan sosial tidak terjadi melalui proses penyesuaian nilai-nilai yang membawa perubahan, tetapi terjadi akibat adanya konflik yang menghasilkan kompromi-kompromi yang berbeda dengan kondisi semula. Teori konflik lahir sebagai sebuah antitesis dari teori struktural fungsional yang memandang pentingnya keteraturan dalam masyarakat. Dahrendorf, Ralf. The Modern Social Conflict: An Essay on The Politics of Liberty, (Stanford CA: University of California Press, 1990), hlm. 106 
Selain itu teori sosiologi konflik adalah alternatif dari ketidakpuasaan terhadap analisis fungsionalisme struktural Talcot Parsons dan Robert K. Merton, yang menilai masyarakat dengan paham konsensus dan integralistiknya.

Perspektif konflik dapat dilacak melalui pemikiran tokoh-tokoh klasik seperti Karl Marx (1818-1883), Emile Durkheim (1879-1912), Max Weber (1864-1920), sampai George Simmel (1858-1918)8.

Keempat pemikiran ini memberi kontribusi sangat besar terhadap perkembangan analisis konflik kontemporer. Satu pemikiran besar lainnya, yaitu Ibnu Khouldoun sesungguhnya juga berkontribusi terhadap teori konflik. Teori konflik Kholdun bahkan merupakan satu analisis komprehensif mengenai horisontal dan vertikal konflik. Proposisi ini dipaparkan dalam rangka untuk memahami dinamika yang terjadi di dalam masyarakat.

Dengan adanya perbedaan kekuasaan dan sumber daya alam yang langka dapat membangkitkan pertikaian (konflik) di masyarakat. Kelompok-kelompok kepentingan yang berbeda dalam sistem sosial akan saling mengejar tujuan yang berbeda dan saling bertanding. Hal ini sesuai dengan pandangan Lock Wood, bahwa kekuatan-kekuatan yang saling berlomba dalam mengejar kepentingannya akan melahirkan mekanisme ketidakteraturan sosial (social disorder). Para teoritis konflik memandang suatu masyarakat terikat bersama adalah kekuatan kelompok atau kelas yang dominan. Para fungsionalis menganggap nilai-nilai bersama (consensus) sebagai suatu ikatan pemersatu, sedangkan bagi teoritis konflik, konsensus itu merupakan ciptaan dari kelompok atau kelas dominan untuk memaksakan,nilai-nilai.

Teori konflik merupakan sebuah pendekatan umum terhadap keseluruhan lahan sosiologi dan merupakan teori dalam paradigma fakta sosial. Mempunyai bermacam-macam landasan seperti teori Marxian dan Simmel. Kontribusi pokok dari teori Marxian adalah memberi jalan keluar terjadinya konflik pada kelas pekerja. Sedangkan Simmel berpendapat 
bahwa kekuasaan otoritas atau pengaruh merupakan sifat kepribadian individu yang bisa menyebabkan terjadinya konflik.

Ketegangan hubungan produksi dalam sistem produksi kapitalis antara kelas borjuis dan proletar mendorong terbentuknya gerakan sosial besar, yaitu revolusi. Ketegangan hubungan produksi terjadi ketika kelas proletar telah sadar akan eksploitasi borjuis terhadap mereka. Sampai pada tahap ini Marx adalah seorang yang sangat yakin terhadap perubahan sosial radikal, tetapi lepas dari moral Marx, esensi akademiknya adalah realitas kekuasaan kelas terhadap kelas lain yang lemah, konflik antar kelas karena adanya eksploitasi itu, dan suatu perubahan sosial melalui perjuangan kelas, dialektika material, yang sarat konflik dan determinisme ekonomi. Pemikiran ini nantinya sangat berpengaruh dan berkembang sebagai aliran Marxis, neoMarxis, madzab Kritis Frankurt, dan aliran-aliran konflik lainnya.

Tindakan afektif individu didominasi oleh sisi emosional, dan tindakan tradisional adalah tindakan pada suatu kebiasaan yang dijunjung tinggi, sebagai sistem nilai yang diwariskan dan dipelihara bersama. Stratifikasi tidak hanya dibentuk oleh ekonomi melainkan juga prestige (status), dan power (kekuasaan/politik). Konflik muncul terutama dalam wilayah politik yang dalam kelompok sosial adalah kelompok-kelompok kekuasaan, seperti partai politik9.

Pokok pikiran Durkheim adalah fakta sosial, Giddens merinci dua makna yang saling berkaitan, dimana fakta-fakta sosial merupakan hal yang eksternal bagi individu. Pertama-tama tiap orang dilahirkan dalam masyarakat yang terus berkembang dan yang telah mempunyai suatu organisasi atau struktur yang pasti serta yang mempengaruhi kepribadiannya. Kedua fakta-fakta sosial merupakan 'hal yang berada di luar' bagi seseorang dalam arti bahwa setiap individu manapun, hanyalah merupakan suatu unsur tunggal dari totalitas pola hubungan yang membentuk masyarakat ${ }^{10}$.

Perkembangan ilmu sosial kemudian memperoleh kesempurnaannya setelah tradisi pemikiran Eropa melahirkan determinisme ekonomi atau

\footnotetext{
${ }^{9}$ Ibid

${ }^{10} \mathrm{Ibid}$
} 
pertentangan kelas dari Marx, teori teori tindakan dan stratifikasi sosial Weber, dan Fakta sosial dari Durkheim ${ }^{11}$.

Teori konflik sebagian berkembang sebagai reaksi sebagi fungsionalisme struktural dan akibat berbagai kritik. Teori konflik ini berasal dari Simmel. Pada 1950-an dan 1960-an, teori konflik menyediakan alternatif terhadap fungsionalime struktural, tetapi dalam beberapa tahun terakhir telah digantikan oleh berbagai macam teori neo-Marxian. Salah satu kontribusi utama teori konflik adalah meletakkan landasan untuk teori-teori yang lebih memanfaatkan pemikiran Marx. Masalah mendasar dalam teori konflik adalah teori itu tak pernah berhasil memisahkan dirinya dari akar struktural-fungsionalnya. Teori ini lebih merupakan sejenis fungsinalisme struktural yang angkuh ketimbang teori yang benarbenar berpandangan kritis terhadap masyarakatnya ${ }^{12}$.

Konflik dapat mengakibatkan adanya perubahan dalam struktur relasi-relasi sosial, apabila kondisi-kondisi tertentu telah dipenuhi. Teori Konflik Ralf Dahrendorf menyatakan bahwa konsekuensi atau fungsi konflik, yaitu dapat mengakibatkan adanya perubahan sosial, khusus yang berkaitan dengan struktur otoritas ${ }^{13}$. Ada tiga tipe perubahan struktur, yaitu (1) perubahan keseluruhan personil dalam posisi dominasi; (2) perubahan sebagian personil dalam posisi dominasi, dan (3) digabungkannya kepentingan-kepentingan kelas subordinat dalam kebijaksanaan kelas yang mendominasi ${ }^{14}$.

Selain itu menurut Teori Konflik Ralf Dahrendorf dinyatakan bahwa perubahan struktural itu dapat digolongkan berdasarkan tingkat ekstremitasnya dan berdasarkan tingkat mendadak atau tidaknya. Dalam hal ini Ralf Dahrendorf mengakui bahwa teorinya yang menekankan pada konflik dan perubahan sosial merupakan perspektif kenyataan sosial yang berat sebelah. Hal tersebut karena meskipun Teori Fungsionalisme Struktural dan Teori Konflik dianggap oleh Ralf Dahrendorf sebagai perspektif valid dalam menghampiri kenyataan sosial, akan tetapi hanya

${ }^{11}$ Ibid

${ }^{12}$ Dahrendorf, Ralf. The Modern Social Conflict: An Essay on The Politics of Liberty, (Stanford CA: University of California Press, 1990), hlm. 108

${ }^{13}$ Ibid

${ }^{14}$ Ibid 
mencakup sebagian saja dari kenyataan sosial yang seharusnya. Kedua teori tersebut tidak lengkap apabila digunakan secara terpisah, dan oleh karena itu harus digunakan secara bersama-sama, agar dapat memperoleh gambaran kenyataan sosial yang lengkap ${ }^{15}$.

\section{Biografi Ralf Dahrendorf}

Ralf Dahrendorf lahir pada tanggal 01 Mei 1929 di Hamburg, Jerman. Ayahnya Gustav Dahrendorf dan ibunya bernama Lina. Tahun 1947-1952, ia belajar filsafat, psikologi, dan sosiologi di Universitas Hamburg, dan tahun 1952 meraih gelar doktor filsafat. Tahun 1953-1954, Ralf melakukan penelitian di London School of Economic, lalu tahun 1956, ia memperoleh gelar Phd di Universitas London. Tahun 1957-1960 menjadi profesor ilmu sosiologi di Hamburg, tahun 1960-1964 menjadi profesor ilmu sosiologi di Tubingen, selanjutnya tahun 1966-1969 menjadi profesor ilmu sosiologi di Konstanz. Menjadi ketua Deutsche Gesellschaft fur Soziologie (1967-1970), dan menjadi anggota Parlemen Jerman di Partai Demokrasi. Tahun 1970, ia menjadi anggota komisi di European Commission di Brussels, dan tahun 1974-1984, menjadi direktur London School of Economics di London.

Kemudian tahun 1984-1986, Ralf menjadi profesor ilmu-ilmu sosial di Universitas Konstanz. Tahun 1986-1997 menetap di Inggris dan menjadi warga negara Inggris pada tahun 1988. Pada tahun 1993, Dahrendorf dianugerahi penghargaan gelar sebagai Baron Dahrendorf oleh Ratu Elizabeth II di Wesminister, London, dan di tahun 2007 ia menerima penghargaan dari Princes of Asturias Award untuk ilmu-ilmu sosial. Karya-karya Ralf Dahrendorf: Class and Class Conflict in Industrial (Stanford University, 1959). The Modern Social Conflict Society (University of California Press: Barkeley dan Los Angeles, 1988), Reflection on The Revolution in Europe (Random House, New York, 1990).

\section{Karya Ralf Dahrendorf}

Teori konflik sebagian berkembang sebagai reaksi terhadap fungsionalisme struktural dan akibat berbagai kritik, yang berasal dari 
sumber lain seperti teori Marxian dan pemikiran konflik sosial dari Simmel. Salah satu kontribusi utama teori konflik adalah meletakkan landasan untuk teori-teori yang lebih memanfaatkan pemikiran Marx. Masalah mendasar dalam teori konflik adalah teori itu tidak pernah berhasil memisahkan dirinya dari akar struktural-fungsionalnya. Teori konflik Ralf Dahrendorf ${ }^{16}$ menarik perhatian para ahli sosiologi Amerika Serikat sejak diterbitkannya buku "Class and Class Conflict in Industrial Society", pada tahun 1959.

Seperti fungsionalis, ahli teori konflik beriorientasi ke studi struktur dan intitusi sosial. Sedikit sekali pemikiran teori ini yang berlawanan secara langsung dengan pendirian fungsionalis ${ }^{17}$. Antitesis terbaiknya ditunjukkan oleh karya Dahrendorf, pendirian teori konflik dan teori fungsional disejajarkan. Dahrendorf adalah tokoh utama yang berpendirian bahwa masyarakat mempunyai dua wajah (konflik dan konsensus) dan karena itu teori sosiologi harus dibagi menjadi dua bagian: teori konflik dan teori konsesus ${ }^{18}$. Teoritisi konsesus harus menguji nilai integrasi dalam masyarakat dan teoritisi konflik harus menguji konflik kepentingan dan penggunaan kekerasan yang mengikat masyarakat bersama di hadapan tekanan itu. Dahrendorf mengakui bahwa masyarakat takkan ada tanpa konsesus dan konflik yang menjadi persyaratan satu sama lain. Jadi, kita tak akan punya konflik kecuali ada konsesus sebelumnya.

Otoritas. Dahrendorf memusatkan perhatian pada struktur sosial yang lebih luas. Inti tesisnya adalah gagasan bahwa berbagai posisi di dalam masyarakat mempunyai kualitas otoritas yang berbeda ${ }^{19}$. Otoritas tidak

16 Teori konflik Ralf Dahrendorf muncul sebagai reaksi atas teori fungsionalisme struktural yang kurang memperhatikan fenomena konflik dalam masyarakat. Teori Konflik adalah suatu perspektif yang memandang masyarakat sebagai sistem sosial yang terdiri atas kepentingan-kepentingan yang berbeda-beda dimana ada suatu usaha untuk menaklukkan komponen yang lain guna memenuhi kepentingan lainnya atau memproleh kepentingan sebesar-besarnya. Dahrendorf, Ralf, Class and Class Conflict in Industrial Society, (Stanford CA: Stanford University. 1959), hlm. 9

${ }^{17}$ Ibid

${ }^{18}$ Ibid

${ }^{19}$ Dahrendorf, Ralf, Scientific-Technological Revolution: Social Aspects, (Stanford CA: Sage Publications (for) the International Sociological Association, 1977), hlm, 69 
terletak di dalam diri individu, tetapi di dalam posisi. Dahrendorf tak hanya tertarik pada struktur posisi, tetapi juga pada konflik antara berbagai struktur posisi itu: "sumber struktur konflik harus dicari dalam tatanan peran sosial yang berpotensi untuk mendominasi atau ditundukkan". Menurut Dahrendorf, tugas pertama analisis konflik adalah mengidentifikasi berbagai peran otoritas di dalam masyarakat. Karena memusatkan perhatian kepada struktur berskala luas seperti peran otoritas itu, Dahrendorf ditentang para peneliti yang memusatkan perhatian pada tingkat individual. Misalnya, ia dikritik oleh orang yang memusatkan perhatian pada ciri-ciri psikologi individu yang menempati posisi itu. Tetapi, menurut Dahrendorf, orang yang melakukan pendekatan demikian bukanlah sosiolog 20 .

Kelompok, Konflik, dan Perubahan. Selanjutnya Dahrendorf membedakan tiga tipe utama kelompok. Pertama adalah kelompok semu (quasi group) atau sejumlah pemegang posisi dengan kepentingan yang sama". Kelompok semu ini adalah calon anggota tipe kedua, yakni kelompok kepentingan. Kedua kelompok ini dilukiskan oleh Dahrendorf seperti berikut.

Metode perilaku yang sama adalah karateristik dari kelompok kepentingan yang direkrut dari kelompok semu yang lebih besar. Kelompok kepentingan adalah kelompok dalam pengertian sosiologi yang ketat, dan kelompok ini adalah agen rill dari konflik kelompok. Kelompok ini mempunyai struktur, bentuk organisasi, tujuan atau program dan anggota perorangan ${ }^{21}$.

Dari berbagai jenis kelompok kepentingan itulah muncul kelompok konflik atau kelompok yang terlibat dalam konflik aktual. Singkatnya Dahrendorf menyatakan bahwa segera setelah kelompok konflik muncul, kelompok itu melakukan tindakan yang menyebabkan perubahan dalam struktur sosial. Bila konflik itu hebat, perubahan yang terjadi adalah radikal. Bila konflik disertai tindakan kekerasan, akan terjadi perubahan struktur secara tiba-tiba. Apa pun ciri konflik, sosiologi harus

\section{${ }^{20}$ Ibid \\ ${ }^{21}$ Ibid}


membiasakan diri dengan hubungan antara konflik dan perubahan maupun dengan hubungan antara konflik dan status quo.

\section{Kritik Utama dan Upaya untuk Menghadapinya}

Teori konflik telah dikritik dengan berbagai alasan. Misalnya, teori ini diserang karena mengabaikan ketertiban dan stabilitas, sedangkan fungsionalisme struktural diserang karena mengabaikan konflik dan perubahan. Teori konflik juga dikritik karena berideologi radikal, sedangkan fungsionalisme dikritik karena ideologi konservatifnya. Apabila dibandingkan dengan fungsionalisme struktural, teori konflik tergolong tertinggal perkembangannya. Teori ini hampir tidak secanggih fungsionalisme, mungkin karena merupakan teori turunan ${ }^{22}$.

Teori konflik Dahrendorf menjadi subjek dari sejumlah analisis kritis, termasuk pemikiran kritis oleh Dahrendorf sendiri. Hasil analisis kritis itu sebagai berikut. Pertama, model Dahrendorf tak secara jelas mencerminkan pemikiran Marxian seperti yang ia nyatakan. Seperti segera akan terlihat, sebenarnya teori konflik ini merupakan terjemahan tidak memadai dari teori Marxian ke dalam sosiologi. Kedua, seperti yang telah dicatat, teori konflik lebih banyak kesamaannya dengan teori fungsionalisme struktural ketimbang dengan teori Marxian. Penekanan Dahrendorf pada hal-hal seperti sistem (asosiasi yang dikoordinasikan secara paksa), posisi peran, secara langsung mengaitkannya dengan fungsionalisme struktural. Akibatnya, teori menderita kekurangan yang sama dengan fungsionalisme struktural. Misalnya, konflik tampak muncul secara misterius dari sebuah sistem yang sah (sebagaimana dalam fungsionalisme struktural). Selanjutnya, teori konflik menderita berbagai maslah konseptual dan logika seperti yang dialami fungsionalisme struktur (misalnya, konsep yang samar-samar tautologi) (Turner, 7975, 1982). Ketiga, seperti fungsinalisme struktural, teori konflik hampir selurunya bersifat makroskopik dan akibatnya sedikit sekali ditawarkan kepada kita untuk memahami pemikiran dan tindakan individu ${ }^{23}$.

\footnotetext{
${ }^{22}$ Ibid

${ }^{23} \mathrm{Ibid}$
} 
Dalam memahami semua gagasan konflik dapat dirangkum dalam beberapa point yaitu (Dahrendorf) 24 :

1. Semakin sedikit kondisi teknikal, sosial, dan politik dari organisasi, semakin hebat konflik yang terjadi.

2. Semakin sedikit mobilitas antara kelompok yang memiliki otoritas, semakin hebat konflik akan terjadi.

3. Semakin sedikit kondisi teknikal, sosial, dan politik dari organisasi, semakin hebat kekerasan akan terjadi.

4. Semakin kecil kemampuan kelompok-kelompok konflik mengembangkan kesepakatan terkait dengan pengaturan, semakin besar kekerasan akan terjadi.

5. Semakin hebat konflik, akan semakin terjadi reorganisasi dan perubahan struktural.

6. Semakin banyak kekerasan ada di konflik, semakin besar tingkatan reorganisasi dan perubahan struktural (lihat juga dalam George Ritzer).

\section{Kajian Kasus Otoritas Konflik Sunni-Syi'ah di Sampang Madura}

Konflik intra agama (Islam) yang terjadi di Kabupaten Sampang merupakan fenomena aktual dalam konstelasi keberagamaan di Madura. Konflik yang kemudian melahirkan kekerasaan terhadap penganut aliran Syi'ah tersebut, tidak hanya sekedar fakta tentang kekerasan, melainkan telah menjadi ancaman bagi harmonisasi atas perbedaan yang ada di Madura $^{25}$. Anarkhisme yang dilakukan oleh oknum penganut aliran tertentu (Sunni) terhadap penganut aliran Syi'ah telah secara perlahan merobohkan bangunan keharmonisan antar aliran keagamaan yang ada di Sampang, dan Madura secara umum²6.

Dalam konteks tersebut, konflik yang terjadi di Sampang Madura pada gilirannya menjadi ancaman terhadap kebebasan dalam memeluk ajaran dan aliran keagamaan sebagaimana diatur dalam Undang-Undang 1945. Artinya, kebebasan beragama memiliki dimensi normatif sebagaimana

${ }^{24}$ Ibid

25 Iik Arifin Mansurnoor, Islam In An Indonesian World: Ulama' of Madura, (Gadjah Mada University Press: Yogyakarta, 1990), hlm. 74

${ }^{26}$ Ibid 
diatur dalam konstitusi, sehingga memilih dan menentukan ideologi dan keyakinan menjadi sesuatu yang dibebaskan. Kebebasan (yang terbuka di era reformasi) memungkinkan kalangan gerakan Islam untuk lebih leluasa menyatakan pendapat, membentuk organisasi, memilih asas/ideologi dan platform, melakukan berbagai kegiatan dakwah dan terjun dalam kegiatan politik praktis.

Oleh karena itu, keberadaan paham atau aliran sejatinya merupakan hak bagi setiap individu bangsa Indonesia untuk menentukan sesuai dengan undang-undang, untuk dikembangkan dan diaktualisasikan dalam batas-batas toleransi dan tidak mengganggu keharmonisan dengan penganut paham atau aliran yang lain. Kondisi itu juga dalam perkembangan berikutnya terjadi di Madura. Banyak aliran atau paham yang kemudian mulai dikembangkan di Madura, termasuk aliran atau paham-paham yang secara umum berlawanan dengan aliran dan paham yang dianut oleh mayoritas masyarakat Madura. Berbagai paham dan aliran keagamaan, selain paham keagamaan yang sudah menjadi mainstream di kalangan masyarakat Madura, seperti NU, dan beberapa paham keagamaan lain yang telah mulai berkembang, seperti Muhammadiyah, Persis, al-Irsyad, Hidayatullah, LDII, dan lain sebagainya, juga sudah mulai berkembang paham-paham keagamaan transnasional seperti Ansorut Tauhid, dan paham Syiah. Paham-paham itu secara perlahan terus berkembang dan mulai tumbuh di tengah-tengah masyarakat Madura.

Menurut Prof. Dr. H. Abdul A'la, MA, bahwa potret masyarakat Madura sebagai masyarakat dengan keberagamaan yang kuat, tetapi sekaligus "dianggap" nyaris lekat dengan tradisi atau budaya yang tidak selamanya mencerminkan nilai-nilai Islam mengisyaratkan tentang kompleksitas kehidupan budaya keagamaan masyarakat Madura itu sendiri27.

Dalam konteks Madura, Syi'ah merupakan paham yang sejak beberapa bulan terakhir ini sempat menjadi sesuatu yang fenomenal, setidaknya setelah terjadinya kekerasan terhadap penganut ajaran Syi'ah di Kabupaten

27 Abd. A'la., Agama Tanpa Penganut : Memudarnya Nilai-Nilai Moralitas dan Signifikansi Pengembangan Teologi Kritis, ( Kanisius: Yogjakarta, 2009), hlm. 84 
Sampang Madura. Konflik yang oleh media dianggap sebagai konflik antar dua paham yang berbeda, yaitu Sunni dan Syi'ah menggambarkan tentang hubungan disharmoni antara kedua aliran tersebut. Sunni yang dalam konteks Madura identik dengan warga NU merupakan penganut terbanyak di Sampang, dan bahkan di Madura. Mayoritas masyarakat Madura merupakan penganut NU, sehingga organisasi ini menjadi paham terbesar yang diyakini oleh masyarakat Madura, khususnya masyarakat Sampang.

Konflik Syi'ah yang berujung dengan perilaku anarkisme merupakan puncak dari ketegangan dua aliran yang berbeda. Pihak Sunni melihat paham Syi'ah sebagai gerakan keagamaan yang berlawanan dengan keyakinan yang dianut oleh masyarakat penganut aliran Sunni, sehingga perbedaan aliran ini menimbulkan resistensi yang kemudian berujung pada konflik kekerasan sosial, budaya, dan ekonomi.

Dalam keterkaitan itu, konflik otoritatif intra agama yang terjadi di Sampang antara aliran Sunni dan Syi'ah merupakan prahara aliran yang telah mereduksi harmonisasi sosial di kalangan masyarakat Sampang dan masyarakat Madura secara umum, sehingga menimbulkan ketegangan sosial yang memanas, dan pada gilirannya akan berujung pada penyuburan benih-benih konflik di tengah-tengah masyarakat.

Aksi kekerasan atas nama agama atau paham tertentu yang terjadi di Madura merupakan fakta menakutkan tentang masa depan kerukunan di Madura yang selama ini dikenal sangat kuat dalam memegang kerukunan antar sesama dalam perbedaan. Tetapi, sejak muncul konflik Sunni Syi'ah Sampang, terlepas apapun motivasinya, telah menggerogoti bangunan kerukukan yang telah lama terjalin di Madura. Untuk itu, perlu dicarikan model resolusi konflik yang tepat, agar konflik intra agama tidak terjadi lagi di Madura secara umum. Maka, keberadaan tokoh masyarakat (ulama) tetap menjadi figur utama dalam mengatasi masalah tersebut ${ }^{28}$.

Apalagi, secara sosiologis, keberadaan ulama di kalangan masyarakat Madura tidak hanya dianggap sebagai elit agama, melainkan juga sebagai pemimpin non formal oleh masyarakat Madura yang dianggap memiliki 
otoritas sosial untuk menentukan hidup dan kehidupan masyarakat. Bagi masyarakat dengan karakteristik agamis seperti Madura, keberadaan ulama adalah sebagai uswatun hasanah, contoh dan model yang baik seluruh perilaku, tindak tanduk, perangai dan tabiat pribadinya bagi para santri dan komunitas di lingkungannya. Pengaruh ulama tidak saja dalam masalah keagamaan, tetapi juga dalam ranah politik. Hal ini terlihat dalam strukturisasi kepemimpinan Madura, yakni Bappa' Babbu'; Guru; Rato. Di mana orang tua, guru (kiai) dan pemimpin formal sebagai bentuk strukturasi kepemimpinan yang harus diikuti oleh masyarakat Madura.

Oleh karena itu, desain kehidupan sosial keagamaan masyarakat Madura, secara faktual berada pada otoritas kalangan ulama sebagai elit sosial utama di Madura yang tidak mustahil akan dipisahkan.

Oleh karena itu, wacana, ideologi, dan praktek keberagamaan masyarakat Madura sangat dipengaruhi oleh kiai dalam menafsirkan agama, budaya, sosial, atau yang lainnya. Mereka beranggapan bahwa kiai mempunyai hak otoritatif untuk menafsirkan wilayah keagamaan, yang kemudian berpengaruh terhadap segala sosial budaya masyarakat. Sedangkan secara ideologis mayoritas pemahaman kiai menganut paham Ahlussunnah Waljama'ah, dengan mendasarkan pada teologi Abu Hasan AlAsyari dan Abu Mansur Al-Maturidy. Dalam bidang ibadah muamalah (fikih) merujuk kepada Imam Syafi'i, meskipun mereka mengakui akan paham imam fikih yang lain, seperti: Imam Hanafi, Imam Maliki, dan Imam Hambali. Dalam bidang keagamaan sufisme lebih mengacu kepada Ghazali dan Junaid Al-Baghdadi. Ideologisasi Ahlussunnah Waljama'ah seperti yang dianut oleh masyarakat dan kiai Nahdlatul Ulama' (NU), dalam proses penafsiran hukum keislamannya (istinbatul hukm), dengan menggunakan penyeimbangan antara dalil naqli dan dalil aqli serta budaya yang berkembang di dalam masyarakat sebagai rujukan utamanya. Ideologi ini menampakkan toleransi yang luar biasa di dalam diri kiai NU yang lebih merorientasikan diri pada penguatan dimensi kultural masyarakat, yang menggunakan pola pendekatan dakwah keagamaan yang tidak bersifat konfrontatif terhadap kekuasaan dan adat istiadat masyarakat, tetapi lebih adaptif terhadap media kultural masyarakat. 
Bahkan tradisi keagamaan saling bersenkritisasi dengan budaya lokal melalui media keberagamaan ${ }^{29}$.

Seperti, media tahlilan. upacara kematian, tahlilan ini tidak hanya dijadikan sebagai media keagamaan yang berorientasi terhadap penghormatan kepada orang yang meninggal atau mengingatkan kita akan kebesaran Tuhan melalui tanda-tanda kematian, namun juga sebagai sarana sosialisasi kemasyarakatan yang saling mendekatkan antarwarga masyarakat sehingga tercipta harmoni di antara mereka. Selain itu, dalam tahlilan kiai bertindak sebagai aktor utamanya, karena dia yang membacakan do'a-do'a tahlil yang diikuti oleh para jama'ah yang hadir.

Bagi masyarakat Madura, kiai bukan hanya dijadikan sebagai tempat rujukan dalam berbagai problematika keagamaan, namun juga bagi kehidupan sosial, budaya, politik, dan ekonomi kemasyarakatan. Siklus kehidupan tentang kelahiran, perkawinan, pertunangan, dan kematian selalu melibatkan peran kiai. Begitu juga dengan kesuksesan dan kemalangan yang dialami oleh masyarakat selalu menyertakan peran kiai, yang melalui do'a-do'anya yang menurut masyarakat lebih didengar dan diperhatikan oleh Tuhan. Para kiai yang diundang selain mendapatkan makanan juga mendapatkan uang atau sering disebut slabet.

Selain itu, kiai mempunyai jaringan antarkiai dengan menggunakan pola semangat kesetaraan. Karena tidak adanya sosok kiai yang memiliki dominasi melalui kekuatan kharismatiknya di tengah masyarakat ${ }^{30}$.

Kemudian, jaringan antarkiai pesantren ini menjadikannya sebagai sarana Islamisasi yang makin mempertebal pengaruh otoritas kiai di tengah masyarakat. Apalagi jaringan ini tidak hanya dibingkai oleh kesadaran kesamaan identitas keislaman, namun dibingkai pula oleh ikatan kekerabatan antarkiai dan perkawinan antarkiai. Selain kiai pesantren, tumbuh dan berkembang juga kiai langgar (surau) yang memiliki hubungan secara langsung dengan masyarakat.

Dengan minusnya perekonomian masyarakat Madura, maka sifat ulet, pekerja keras, dan tidak pernah pilih-pilih pekerjaan merupakan bagian dari etos kerja mereka, yang mempunyai semboyan "abhenthal ombhe' asapo'

\footnotetext{
${ }^{29}$ Ibid

${ }^{30} \mathrm{Ibid}$
} 
angin" (berbantalkan ombak berselimutkan angin), yang merupakan spirit kerja mereka yang tidak hanya terbatas pada etos kerja kelautan saja tapi juga pada energisitas kehidupan masyarakat. Kerja keras tersebut sudah mulai awal menjadi prinsip dasar masyarakat Madura untuk memenuhi kebutuhan primer dan sekundernya.

Seiring dengan hal tersebut, maka masyarakat Madura seringkali digambarkan sebagai orang dengan sosok yang kasar, suka berkelahi, kaku, garang, dan menakutkan, serta berani. Sehingga mereka dapat dibedakan dengan mudah dengan orang Jawa, karena mereka kasar, tidak tahu sopan santun, terbuka, banyak bicara, dan tidak halus. Di samping stereotipe negatif tersebut, terdapat pula karakteristik positif, yakni berani, petualang, loyal, rajin, hemat, menyenangkan, antusias, dan humoris. Akan tetapi stereotipe yang negatiflah yang lebih menonjol dialamatkan terhadap masyarakat Madura. Stereotipe tersebut tidak hanya berlaku pada laki-laki namun juga pada perempuannya tidak terkecuali anak-anak. Perempuannya seringkali diidentikan dengan kerampingan, dada bagus, dan excellent sexual intercourse. ${ }^{31} \mathrm{Hal}$ ini diperkuat dengan kondisi alam, ekonomi, sosial budaya, dan politik masyarakatnya sehingga stereotipe tersebut tumbuh dengan subur. Alamnya yang tidak subur, kemiskinan pada mayoritas masyarakatnya, telah memunculkan atau memaksa mereka bermigrasi, sehingga menimbulkan stereotipe mereka kasar, keras, berani, kuat, ulet, dan hemat. Sementara dengan kurangnya kadar air di wilayahnya serta kerasnya hidup telah membuat tubuh mereka kekurangan air, sehingga perempuannya dimitoskan lebih manis. Selain itu, karena kadar airnya yang lebih banyak tercampur garam maka perempuannya distereotipekan dengan wanita yang sempurna seksualitasnya, karena keringnya vagina mereka. Hal inilah yang menyebabkan banyak jamu yang berhubungan dengan keharmonisan pasangan suami istri yang berasal dari Madura. Padahal banyak yang memproduksi jamu-jamu tersebut di luar Madura dan bahkan bahanbahan pembuatannya dari luar Madura. 
Lebih lanjut, masyarakat Madura secara ekologi terdiri dari tegalan, bukan sawah. Oleh karena itu ekosistem di desa Guluk-guluk dan Prenduan ditandai oleh pola pemukiman penduduk pedesaan yang terpencar-pencar dalam kelompok-kelompok kecil yang dikelilingi oleh tegal, atau biasa disebut sebagai pemukiman kampong meji (kampung meji), yaitu kelompok pemukiman penduduk desa yang satu sama lainnya terpisah atau terisolasi. Keterisolasian kelompok pemukiman penduduk desa semakin nyata dengan adanya pagar yang umumnya berupa rumpun bambu (meskipun sekarang sudah mulai banyak pagar dari semen). Antara kelompok pemukiman yang satu dengan kelompok pemukiman yang lain biasanya dihubungkan oleh jalan desa atau jalan setapak.

Kelompok-kelompok pemukiman rumah-rumah keluarga terhimpun dalam pola pemukiman pamengkang, pola pemukiman koren, pola pemukiman kampong meji, dan pola pemukiman tanean lanjang. Pada pola pemukiman pamengkang dan pola pemukiman koren jumlah rumah maupun generasi keluarganya belum banyak jumlahnya. Sedangkan pada pola pemukiman kampong meji dan pola pemukiman tanean lanjang jauh lebih banyak jumlah rumahnya, dan bisa mencapai lima generasi keluarga ${ }^{32}$. Pola pemukiman tanean lanjang atau dalam bahasa Indonesianya halaman panjang, merupakan salah satu pola pemukiman masyarakat Madura (Wiryoprawiro, 1986), dan merupakan bentuk pemukiman yang tertua di Madura. Apabila dilihat dari sejarah dan susunan yang bermukim di dalamnya, pola pemukiman tanean lanjang dibangun oleh keluarga yang mempunyai banyak anak perempuan, dengan sistem pernikahan uxorimatrilocal, yang banyak dipakai oleh masyarakat Madura, yang artinya anak perempuan yang menikah tetap tinggal di pekarangan orang tuanya sementara suaminya pindah ke pekarangan istrinya. Untuk membangun pola pemukiman tanean lanjang hanya dapat dilakukan oleh keluarga yang mampu secara ekonomi. Rumah-rumah yang terdapat dalam pola pemukiman tanean lanjang selalu dibangun berderet dari barat ke timur dan menghadap ke selatan, sebagaimana posisi rumah tradisional lainnya. Rumah itu dideretkan 
dimulai dari keluarga tertua atau anak perempuan termuda di sebelah timur, semuanya menghadap ke selatan.

Melihat dari formasi yang terdapat pada pola pemukiman tanean lanjang tampak jelas bahwa dalam ideologi keluarga masyarakat Madura mempunyai proteksi yang sangat khusus terhadap perempuan jika dibandingkan dengan laki-laki. Setiap orang tua akan selalu menginginkan anak perempuannya untuk tetap tinggal bersama mereka di lingkungannya, meskipun mereka sudah bersuami. Perhatian dan proteksi masyarakat terhadap kaum perempuan tidak hanya terlihat pada struktur formasi pola pemukiman tanean lanjang namun terdapat pula pada struktur formasi seluruh pola pemukiman tradisional masyarakat Madura. Setiap rumah yang ada di masyarakat Madura mesti akan memiliki sebuah langgar atau surau, dan lokasinya berada di ujung halaman bagian barat sebagai simbolisasi Ka'bah yang merupakan kiblat umat Islam ketika sholat. Langgar tersebut tidak hanya berfungsi atau bermakna sebagai tempat ritualitas keagamaan belaka, namun secara kultural memiliki fungsi yang bermakna sebagai tempat untuk menerima semua tamu laki-laki. Tujuannya adalah menempatkan semua tamu laki-laki di langgar untuk mencegah kemungkinan terjadinya perilaku-perilaku negatif bernuansa seksualitas akibat pertemuan antara laki-laki tersebut dengan anggota keluarga perempuan (terutama istri) dari pihak tuan rumah. Karena hal ini dianggap sebagai parseko (tidak etis) apabila menerima tamu laki-laki di ruang tamu kecuali tamu yang masih kerabat sendiri. Sedangkan segala bentuk gangguan terhadap kehormatan kaum perempuan (terutama istri) akan selalu dimaknai sebagai pelecehan terhadap kehormatan laki-laki, sehingga mereka rela untuk mempertahankan kehormatannya meski harus lewat pertarungan carok yang akan menyebabkan nyawanya hilang33.

Selain pola pemukiman tanean lanjang dan terbentuknya solidaritas masyarakat desa melalui langgar dan otoritas kiai, masyarakat Madura juga mengenal pola perkawinan endogami, yakni kecenderungan menikah dengan kerabat sendiri, terutama sepupu, yang dalam istilah Madura dikenal dengan "mapolong tolang" (ngumpulin tulang). Tujuan perkawinan

\section{${ }^{33}$ Ibid}


ini adalah untuk mempertahankan ikatan tali keluarga, sedangkan untuk keluarga menengah ke atas, perkawinan model ini sangat penting untuk mempertahankan kekayaannya agar tidak jatuh ke tangan keluarga yang lain. Bahkan dalam realitas kehidupan masyarakat Madura, biasanya menjodohkan anaknya yang masih berumur di bawah lima tahun (balita) dengan anak dari keluarga yang lain -baik kerabat sendiri atau tidak- pada usia yang sama. Hal ini yang menyebabkan banyaknya terjadi kawin paksa, meskipun angka penceraian sangat kecil. Tujuan perjodohan pada usia muda atau kecil tersebut selain menjaga kekerabatan juga untuk menjaga kehormatan keluarga dari perasaan aib dan malu jika pada waktunya anak perempuan mereka belum mendapatkan jodohnya. Karena menurut mereka seorang perempuan seharusnya sudah menikah tidak lama setelah mengalami haid pertama, yakni sekitar umur 13-17 tahun.

Apabila telah melewati umur tersebut masyarakat akan mencemoohnya sebagai perempuan yang tidak laku ( $t a^{\prime}$ paju lake). Sedangkan pada laki-laki tidak ada istilah tersebut, sehingga banyak masyarakat Madura yang memperbolehkan anak perempuannya untuk diperistri lebih dari satu (poligami), ketimbang disebut sebagai perempuan yang tidak laku. Selain itu, bentuk patriarkhal masyarakat dalam kehidupan keluarganya juga dicerminkan oleh superordinasi laki-laki (suami) terhadap perempuan (istri) ${ }^{34}$.

Ketundukan masyarakat Madura terhadap kiai dan kedudukannya yang begitu dihormati, tergambar secara struktural dalam bangunan sosial masyarakatnya. Buppa' (bapak), Babu' (ibu), Guruh (guru/kiai), Ratoh (raja), adalah pelambangan unsur-unsur dalam bangunan sosial masyarakat Madura. Jika Buppa' dan Babu' merupakan elemen penting dalam keluarga di desa tersebut, maka Guruh dan Ratoh adalah penentu dalam dinamika sosial, politik, ekonomi dan budaya masyarakat Madura. Bangunan sosial ini menggambarkan kepatuhan masyarakat di Madura pada bapak dan ibunya, juga ketundukan terhadap tokoh panutan (guru/kiai) dan kepada pemerintah. Tokoh panutan biasa disebut pemimpin informal. Pemimpin informal adalah orang yang memimpin masyarakat atau sekelompok

34 Abdur Rozaki, Menabur Kharisma Menuai Kuasa: Kiprah Kiai dan Blater Sebagai Rezim Kembar Di Madura, (Pustaka Marwa: Yogyakarta, 2004), hlm. 64 
masyarakat tanpa mendapatkan loyalitas pemerintah, seperti; ulama', kiai, sesepuh, tokoh-tokoh desa, dan sebagainya. Sedangkan pemimpin informal dan figur yang dipatuhi dalam masyarakat Madura yang perilakunya bertentangan dengan kiai, adalah orang blater. Orang blater secara kultural mendapat legitimasi sebagai figur yang dipatuhi. Hal ini dikarenakan tidak semua masyarakat di Madura "terseret" ke dalam wacana dan ritual keagamaan yang dibawa oleh agen sosial desa dalam hal ini kiai, seperti dalam pengamatan Kuntowijoyo. Struktur ekologi pertanian tegalan yang tidak produktif tersebut yang melahirkan proses sosiokultural yang tidak selalu merujuk pada keberagamaan yang dibawa para otoritasnya (kiai). Realitas sosial tersebut yang kemudian melahirkan eksistensi komunitas blater. Mereka mempunyai perilaku yang bertentangan dengan agama dan kiai, sehingga mereka diidentikkan dengan perilaku atau perbuatan hitam, seperti: berjudi, minum-minuman keras, main perempuan, sering melakukan remo ${ }^{35}$ dan carok $^{36}$, serta merampok atau mencuri. Dalam hal tertentu orang blater sangat tunduk kepada kiai, pertama, karena pada umumnya orang blater masih berguru kepada kiai. Kedua, kesaktian orang blater (seperti tidak mempan dibacok senjata tajam) karena diberi do'a-do'a oleh kiai (jimat).

\section{Potret Konflik Intra Agama Di Sampang}

Konflik keagamaan di Madura tepatnya di Kabupaten Sampang antara Sunni-Syi'ah sudah terjadi sejak tahun 2004. Yang kemudian berlanjut menjadi konflik pada tahun 2011, dan terakhir pada hari Minggu tanggal

${ }^{35}$ Remo adalah acara yang dilengkapi hiburan seperti sandur, hiburan yang disajikan dalam remo adalah sandur Madura yaitu suatu jenis kesenian tradisional semacam ludruk yang dimeriahkan oleh penari (tand $a^{\prime}$ ) laki-laki dengan diiringi oleh gamelan. Dengan adanya kesenian tersebut maka seorang blater dapat menunjukkan kapasitasnya sebagai seorang jagoan, dengan menari dengan jenis tarian tertentu yang sesuai dengan pilihannya. A Latief Wiyata., Op. Cit, hlm. 71

36 Carok adalah berkelahi satu lawan satu atau lebih atau berkelompok dengan menggunakan senjata tajam, yang biasanya dikenal dengan celurit. Untuk lebih lanjut mengetahui tentang kekerasan di Madura, lihat Elly Touwen Bouwsma., 1989, "Kekerasan di Masyarakat Madura", dalam Huub de Jonge (edit), Agama, Kebudayaan dan Ekonomi: Studi-studi Interdisipliner Tentang Masyarakat Madura, terj. Suparmin, Rajawali Pers: Jakarta, hlm. 159-179 
26 Agustus 2012, yang menyebabkan kerugian material maupun non material, yakni pembakaran 37 rumah pengikut Syiah, pelemparan batu, dan perkelahian hingga mengakibatkan satu korban meninggal dunia dan puluhan orang luka-luka. Bahkan Kapolsek Omben, AKP Aris, turut menjadi korban dalam bentrokan tetsebut. Kapolsek dikabarkan mengalami luka parah akibat sabetan parang. Organisasi keagamaan di Madura mayoritas adalah NU, sedangkan aliran keagamaan lainnya seperti, Muhammadiyah, LDII, KTI, Syiah, merupakan kelompok keagamaan Islam yang minoritas.

Kedatangan atau pengenalan aliran Syi'ah bermula sejak awal tahun 1980-an, di mana pada waktu itu ada seorang kiai, yang bernama kiai Makmun, yang sebenarnya adalah kiai NU di desa Nangkernang, Desa Karang Gayam, Sampang, mendapatkan kabar dari salah satu sahabatnya di Iran mengenai revolusi Iran. Keberhasilan kaum ulama Iran yang dipimpin Ayatollah Ali Khomeini menumbangkan Syah Iran Reza Pahlevi (sebuah rezim yang dianggap monarki) menjadi sumber inspirasi bagi Kiai Makmun. Karena mayoritas ulama dan kaum muslim di wilayah Madura adalah pengikut Islam NU yang fanatik, kemudian mulailah kiai Makmun mempelajari Syiah secara diam-diam dengan membaca buku-buku yang dikirim sahabatnya dari $\operatorname{Iran}^{37}$.

Berawal dari ketertarikannya yang bermula dari suksesnya revolusi Iran, dengan mulai mempelajari kitab-kitab aliran Syi'ah, maka pada tahun 1983 kiai Makmun mengirimkan empat anaknya untuk belajar tentang aliran Syi'ah ke pondok pesantren Yayasan Pesantren Islam (YAPI) di Bangil Pasuruan, yaitu: Iklil al Milal; Tajul Muluk; Roisul Hukama; dan putrinya, Ummi Hani. Pada tahun 1991, Tajul Muluk lulus SMP YAPI dan kembali ke Sampang. Kemudian pada tahun 1993 Tajul Muluk melanjutkan pembelajarannya tentang aliran Syi'ah ke ke Arab Saudi untuk belajar di Pondok Pesantren Sayyid Muhammad Al-Maliki. Pada tahun 1999, Tajul Muluk pulang dari Arab Saudi dan kembali menetap di Karang Gayam, Sampang. Pada tahun 2004, sejumlah warga yang juga merupakan santri dari kiai Makmun mewakafkan sejumlah tanahnya untuk proses

37 Iskandar Dzulkarnain, Dekonstruksi Sosial Budaya Alaq Dalaq Di Madura, (Pararaton: Jogjakarta, 2012), hlm. 47 
pengembangan dan penyebaran ajaran keagamaannya, yang kebetulan aliran Syi'ah. Pesantren ini kemudian diberi nama Misbahul Huda. Para kiai (ustadz) yang mengajar selain Tajul Muluk bersama semua saudarasaudaranya, juga beberapa alumni alumni pondok pesantren YAPI.

Sejak saat itulah pengembangan syiar aliran Syi'ah berkembang dengan dikendalikan oleh kepemimpinan kiai Tajul Muluk. Pola dakwah yang berbeda dengan sang Bapak kiai Makmun, di mana kiai Tajul Muluk mengajar dan berdakwah aliran Syiah secara terbuka dan terang-terangan. Pola dakwah dan sikap serta perilaku kiai Tajul Muluk yang egaliter, supel, ringan tangan, cekatan, dan tidak bersedia menerima imbalan setiap ceramah membuat dirinya menjadi kiai muda yang dihormati di Karang Gayam.

Perkembangan yang sangat pesat dari penyebaran aliran Syi'ah yang dilakukan oleh kiai Tajul Muluk, membuat resah dan respon yang luar biasa dari para kiai NU, dan itu mulai awal tahun 2004. Respon itu di antaranya dilakukan oleh Kiai Ali Karrar Shinhaji (masih kerabat dekat dari ayah Tajul, Kiai Makmun), pimpinan pondok pesantren Darut Tauhid, di Desa Lenteng, Kecamatan Proppo, Pamekasan. Beliau melarang dan sangat berkerabatan terhadap aktivitas dakwah kiai Tajul Muluk yang mengajarkan Syiah. Bagi kiai Ali Karrar Shinhaji, aliran Syiah adalah mazhab dalam Islam yang salah dan sesat. Tak hanya Kiai Ali Karrar Shinhaji, para kiai lain di kabupaten Sampang juga bersikap sama: keberatan dengan aktivitas Kiai Tajul Muluk. Namun, pada saat itu, para kiai tidak terbuka menentang dakwah Kiai Tajul Muluk karena masih menaruh rasa hormat terhadap Kiai Makmun. Dan konflik itu semakin menguat sejak bulan Juni 2004, sejak kiai Makmun meninggal. Sejak saat itulah, para kiai menentang keras penyebaran Syiah yang dilakukan oleh anak-anak Kiai Makmun. Intimidasi dan kekerasan terhadap komunitas minoritas Syiah Sampang yang dianggap sesat mulai kerap terjadi sejak saat itu ${ }^{38}$.

Konflik keagamaan Syi'ah-Sunni yang terjadi di Sampang pada tahun 2012 berawal dari rombongan siswa dari komunitas aliran Syiah yang akan

38 Tempo.co, Minggu, 02 September 2012: Bagaimana Kronologi Syi’ah Masuk Sampang 
kembali ke Pondok Pesantren YAPI di Bangil, Pasuruan. Saat hendak kembali itulah, puluhan massa sudah menghadang dan mengancam akan membakar dan membunuhnya. "Anak-anak komunitas tersebut akan kembali ke Bangil setelah mengikuti Lebaran," kata Kulsum, istri kiai Tajul Muluk, pimpinan pondok pesantren kelompok aliran Syiah. Akibat konflik itulah maka kemudian Kiai Tajul Muluk divonis dua tahun penjara oleh Pengadilan Negeri Sampang karena dituduh melakukan penodaan agama.

Pelarangan dan penghadangan para santri YAPI yang beraliran Syiah itu kemudian berlanjut dengan aksi pembakaran pekarangan rumah mereka di 20 titik. Jumlah rumah yang terbakar mencapai 37. Sekelompok massa itu menyerbu dan mendatangi rumah istri Kiai Tajul Muluk. Rumah Kiai Tajul Muluk pernah dibakar oleh sekelompok pemuda yang mengatasnamakan anti Syiah pada akhir Desember 2011. Namun rumah dari sisa-sia kebakaran yang ditempati oleh Ny Kulsum, istri kKai Tajul Muluk, beserta dua anaknya itu pun kembali dibakar oleh para pemuda anti Syiah, yang kemudian dikenal sebagai pemuda aliran Sunni. Aksi pembakaran mengakibatkan bentrok antara dua kelompok aliran keagamaan Sunni-Syi'ah. Pemuda dari komunitas aliran Syiah yang ingin melindungi keluarga Kiai Tajul Muluk membalas aksi pelemparan dari sekelompok massa aliran Sunni. Belasan rumah milik pengikut Syiah hangus rata menjadi tanah. Setelah membakar belasan rumah pengikut aliran Syiah, ribuan massa dari kelompok Sunni mulai melakukan penyisiran dengan bergerombol di sekitar SDN Karang Gayam, Omben, Sampang yang diduga menjadi tempat persembunyian beberapa warga Syiah. Hingga minggu malam, beberapa rumah pengikut Syiah masih mengepulkan asap pasca pembakaran oleh massa Sunni.

Sebenarnya konflik keagamaan antara aliran Syiah-Sunni di Sampang, Madura ini bermula dari konflik pribadi antara pimpinan Islam Syiah Kiai Tajul Muluk dengan saudaranya adiknya, yaitu Kiai Rois, yang beraliran Sunni.

Konflik keluarga kemudian dibawa ke medan perselisihan mazhab. "Persoalan mendasar yang memalukan ini tidak banyak diketahui orang. Media dan tokoh agama lebih sibuk membincang masalah konflik antara Sunni dan Syiah," ujarnya. Dari konflik keluarga itu, lalu meluas menjadi 
konflik keagamaan setelah di kalangan pengikut Islam Sunni tersiar kabar bahwa aliran Islam Syiah merupakan aliran Islam sesat, sehingga pengikut Islam Sunni beramai-ramai mengusir pengikut Syiah yang ada di wilayah Kecamatan Omben dan Kecamatan Karangpenang. Dan bentrokan keagamaan itu juga pernah terjadi pada 29 Desember 2011. Kala itu terjadi pembakaran rumah, madrasah, mushalla dan pesantren kelompok Islam Syiah. Sebanyak 335 orang pengikut aliran Islam Syiah dari total 351 orang lebih dievakuasi ke GOR Wijaya Kusuma depan kantor Bupati Sampang akibat kerusuhan yang terjadi ketika itu ${ }^{39}$.

Dan sejak saat ittulah Kiai Roisul Hukama (Kiai Rois) dijadikan tersangka oleh pihak kepolisian mengikuti jejak pidana sang kakak Kiai Tajul Muluk. Menurut Kiai Rois konflik keagamaan ini bermula dari gaya berdakwah kakaknya yang terlalu keras. Hal itu membuat banyak warga Nangkernang yang suami-istri bercerai atau ayah dan anak berselisih karena dalam satu rumah ada yang menganut Syiah dan Sunni.

Sedangkan menurut Jalaluddin Rakhmat, masalah konflik yang terjadi di Sampang bukan persoalan keluarga. "Bukan konflik saudara yang mengatasnamakan agama, tapi kefanatikan agama yang menggunakan masalah keluarga". Menurutnya hal ini disebabkan oleh komunitas Syiah di Sampang yang lebih lemah daripada daerah lain. Mereka pun bukan datang dari kalangan terpelajar atau berekonomi mapan. "Sedangkan orang yang menyerang mendapat sokongan dana hingga bisa datang menggunakan bus sewaan". Bukan hanya itu, keberadaan aliran Syiah di Sampang semakin terimpit ketika Majelis Ulama Indonesia di Jawa Timur mengeluarkan fatwa bahwa aliran Syi'ah itu sesat. Bahkan mantan Menteri Agama Suryadharma Ali waktu itu pernah setuju dengan putusan tersebut. Lebih lanjut, menurutnya sebetulnya masyarakat tak membenci umat Syiah. Ketidaksukaan itu muncul karena bisikan kiai mereka. Apalagi seperti masyarakat tradisional yang ada di Sampang, mereka sebenarnya lebih memilih bertani, untuk mencari makan, sementara soal problematika keagamaan diserahkan kepada kiai. "Penduduk merasa tidak memiliki otoritas pemahaman soal agama. Sehingga, otorisasi kebenaran keagamaan

\footnotetext{
${ }^{39}$ www.gatra.com, 27 Agustus 2012: Syiah-Sunni Membara, Sampang Berdarah
} 
ada di tangan kiainya. Karena itu, fatwa MUI Jawa Timur sungguh berpengaruh besar terhadap penyerangan Syiah. Sebab, masyarakat Madura cenderung akan patuh dan ikut apa kata kiainya. "Preman saja hormat pada kiai," 40

\section{Simpulan}

Asumsi Dahrendorf tentang masyarakat ialah bahwa masyarakat setiap saat tunduk pada proses perubahan, dan pertikaian serta konflik ada dalam sistem sosial juga berbagai elemen kemasyarakatan memberikan kontribusi bagi disintegrasi dan perubahan. Suatu bentuk keteraturan dalam masyarakat berasal dari pemaksaan terhadap anggotanya oleh mereka yang memiliki kekuasaan, sehingga ia menekankan tentang peran kekuasaan dalam mempertahankan ketertiban dalam masyarakat.

Bagi Dahrendorf, masyarakat memiliki dua wajah, yakni konflik dan konsesus yang dikenal dengan teori konflik dialektika. Dengan demikian diusulkan agar teori sosiologi dibagi menjadi dua bagian yakni teori konflik dan teori konsensus. Teori konflik harus menguji konflik kepentingan dan penggunaan kekerasan yang mengikat masyarakat sedangkan teori konsensus harus menguji nilai integrasi dalam masyarakat. Bagi Dahrendorf, masyarakat tidak akan ada tanpa konsensus dan konflik. Masyarakat disatukan oleh ketidakbebasan yang dipaksakan. Dengan demikian, posisi tertentu di dalam masyarakat mendelegasikan kekuasaan dan otoritas terhadap posisi yang lain.

Dari berbagai persoalan konflik keagamaan antara Sunni-Syi'ah di Sampang seharusnya perlu dibaca secara utuh, dalam artian bahwa ketika kita berbicara tentang konflik keagamaan di Madura maka kita harus melihat kondisi sosial budaya dan keagamaan masyarakat Madura, termasuk di dalamnya persoalan kepemimpinan lokal keagamaan Madura. Dan ini sangat penting bagi para pengambil kebijakan dalam menyelesaikan konflik keagamaan di Indonesia terutama di Madura dan khususnya di Sampang, sehingga konflik keagamaan bisa diselesaikan tidak terjadi secara berulang-ulang bahkan sampai tiga kali. 
Pemahaman yang utuh itu pada akhirnya akan menciptakan pemahaman yang utuh tentang persoalan konflik yang terjadi di Sampang, apakah konflik keagamaan, konflik keluarga, konflik otoritasi politik lokal, ataukah konflik sosial lainnya. Namun, yang pasti di Sampang telah terjadi konflik keagamaan yang berawal dari konflik keluarga.

\section{DAFTAR PUSTAKA}

Abdurrachman. 1971. Sejarah Madura Selajang Pandang. Sumenep: Automatik The Sun.

As, Muhammad Syamsu. 1999. Ulama Pembawa Islam di Indonesia dan Sekitarnya, Jakarta: Lentera, 1999.

A'la, Abd. 2009. Agama Tanpa Penganut : Memudarnya Nilai-Nilai Moralitas dan Signifikansi Pengembangan Teologi Kritis. Yogjakarta: Kanisius.

Boland, B. J. 1985. Pergumulan Islam di Indonesia 1945-1970, (terj.) Saafroedin Bahar, dari Judul Asli The Struggle of Islam in Modern Indonesia, Jakarta: Grafiti Pers.

Coser, Lewis. 1957. Social Conflict and The Theory of Social Change, British Journal of Sociology 8:3 Sept. 1957.

Dahrendorf, Ralf. 1959. Class and Class Conflict in Industrial Society. Stanford CA: Stanford University.

Dahrendorf, Ralf. 1990. The Modern Social Conflict: An Essay on The Politics of Liberty. University of California Press.

Dahrendorf, Ralf. 1977. Scientific-Technological Revolution: Social Aspects. Sage Publications (for) the International Sociological Association. 
Dzulkarnain, Iskandar. 2012. Dekonstruksi Sosial Budaya Alaq Dalaq Di Madura. Yogjakarta: Pararaton.

Hamka. 1961. Sejarah Perkembangan Pemurnian Ajaran Islam di Indonesia, Teks Pidato ketika Menerima Gelar Doktor Honoris Causa (Dr.HC.) Tahun 1958 dari Universitas Al-Azhar Mesir, Jakarta: Tintamas.

Jaringan Kerjasama Antar Umat Beragama. 2002. Dari Wacana Ke Aksi Nyata, Jakarta: Titahandalusia Press.

Jonge. Huub de. 1989. Madura dalam Empat Zaman: Pedagang, Perkembangan Ekonomi dan Islam: Suatu Studi Antropologi Ekonomi. Jakarta: Gramedia.

Jonge, Huub de. 1991. "Stereotypes of the Madurese", Royal Institute of Linguistics and Anthroppology, International Workshop on Indonesian Studies, No. 6, Leiden, 7-11 October 1991.

Kahin, Audrey R. 1989. Pergolakan Daerah pada Awal Kemerdekaan. Jakarta: Pustaka Utama Grafiti.

Kuntowijoyo. 1993. Radikalisasi Petani. Jogjakarta: Bentang.

Morey, Robert A. 2004. The Islamic Invasion (Islam Yang Dihujat). Bekasi: Focus Muslimedia.

Ricklefs, M. C. 2008. Sejarah Indonesia Modern 1200-2008. Jakarta: Serambi.

Ritzer, George dan Goodman, J. Douglas. 2007. Teori Sosiologi Modern. Jakarta: Prenada Media Group.

Rozaki, Abdur. 2004. Menabur Kharisma Menuai Kuasa: Kiprah Kiai dan Blater Sebagai Rezim Kembar di Madura. Yogyakarta: Pustaka Marwa.

Tugiyono KS, dkk. 2004. Pengetahuan Sejarah Sosial 2. Jakarta: Grasindo.

Wulan, Sari Dewi. 2009. Sosiologi dan Konsep Teori. Jakarta: Refika Aditama. 